\title{
IMPLEMENTASI KURIKULUM 2013 DALAM PEMBELAJARAN KIMIA KELAS X SMA SE-KOTA JAYAPURA
}

\author{
Teguh Iman Santosa ${ }^{1)}$ dan Tiurlina Siregar ${ }^{2)}$ \\ ${ }^{1)}$ Alumni Program Studi Magister Pendidikan IPA Universitas Cenderawasih \\ ${ }^{2)}$ Dosen Program Studi Magister Pendidikan IPA Universitas Cenderawasih
}

\begin{abstract}
This study aimed to evaluate the feasibility of learning applied chemistry teacher of class X associated with the implementation of Curriculum 2013 in the schools, the results of the analysis of these implementations will be referred to the standardization that has been set by the Minister of Education as a reference implementation of Curriculum 2013. This type of research is research qualitative evaluative. The method or technique of collecting data is interactive and non-interactive. Results of the study subjects chemistry class $X$ Curriculum 2013 are guided by the Permendikbud No. 59 of 2014, Permendikbud No. 103 of 2014 and Permendikbud No. 1042014 shows (1) In the learning plan can be implemented and supported by the results of the questionnaire teachers who achieve $86 \%$ success rate (2) Implementation of the learning can be implemented and supported by the results of the questionnaire teachers who achieve $86 \%$ success rate. (3) the learning process can be accomplished in accordance with and supported by the results of the questionnaire teachers who achieve $81 \%$ success rate. (4) Assessment of learning outcomes can be accomplished and supported by the results of the questionnaire teachers who achieve $87 \%$ success rate. The results showed that the implementation of the curriculum in 2013 subjects chemistry class $X$ as determined by Permendikbud No. 59 of 2014, Permendikbud No. 103 of 2014.
\end{abstract}

Keywords: Implementation, Curriculum 2013, Chemistry.

Abstrak. Penelitian ini bertujuan untuk mengevaluasi keterlaksanaan pembelajaran yang diterapkan guru mata pelajaran kimia kelas X terkait dengan implementasi Kurikulum 2013 yang ada di sekolah tersebut, hasil analisis implementasi tersebut akan dirujuk pada standarisasi yang telah ditetapkan oleh Permendikbud sebagai acuan pelaksanaan Kurikulum 2013. Jenis penelitian ini adalah penelitian kualitatif yang bersifat evaluatif. Metode atau teknik pengumpulan data yang dilakukan bersifat interaktif dan non-interaktif. Hasil penelitian mata pelajaran kimia kelas X Kurikulum 2013 yang berpedoman kepada Permendikbud Nomor 59 Tahun 2014,dan Permendikbud Nomor 104 Tahun 2014 menunjukkan (1) Pada perencanaan pembelajaran dapat terlaksana serta didukung dengan hasil angket guru yang mencapai 86\% tingkat keberhasilannya (2) Pelaksanaan pembelajaran dapat terlaksana dan didukung dengan hasil angket guru yang mencapai 86\% tingkat keberhasilannya. (3) Penilaian proses pembelajaran dapat terlaksana dan didukung dengan hasil angket guru yang mencapai $81 \%$ tingkat keberhasilannya. (4) Penilaian hasil pembelajaran dapat terlaksana dan didukung dengan hasil angket guru yang mencapai $87 \%$ tingkat keberhasilannya. Hasil penelitian ini menunjukkan bahwa implementasi kurikulum 2013 mata pelajaran kimia kelas X telah sesuai dengan yang ditetapkan oleh Permendikbud Nomor 59 Tahun 2014, Permendikbud Nomor 103 Tahun 2014.

Kata kunci : Implementasi, Kurikulum 2013, Kimia 


\section{PENDAHULUAN}

Kurikulum 2013 dikembangkan dengan landasan filosofis yang memberikan dasar bagi pengembangan seluruh potensi peserta didik menjadi manusia Indonesia berkualitas yang tercantum dalam tujuan pendidikan nasional. Untuk menerapkan Kurikulum 2013 diperlukan wadah yaitu sekolah. Berdasarkan data yang diperoleh di Indonesia ada $2.598 \mathrm{SD}, 1.521 \mathrm{SMP}, 1.270$ SMA, dan 1.021 SMK telah memakai Kurikulum 2013 (http://www.kemdikbud.go.id/kemdikbud/b erita/1309). Selain itu, menurut Kepala Dinas Pendidikan dan Kebudayaan Papua, Elias Wonda (Tahun 2014) saat pencanangan Kurikulum 2013 di Jayapura mengatakan pembagian lima region pelaksana Kurikulum 2013 diantaranya region Jayapura, Region Merauke, Region Nabire, Region Biak dan Region Wamena. (http://www.nabire.net/penerapankurikulum-2013-di-papua).

Pada Tahun 2013 Kemendikbud melalui Direktorat Pembinaan Sekolah Menengah Atas mengeluarkan Surat Keputusan Nomor 2647/D2/KP/2013 tentang Penetapan Kelompok (Cluster) Pendampingan dalam Rangka Implementasi Kurikulum 2013 dengan menetapkan 127 SMA sebagai koordinator cluster dan 1.146 SMA lainnya sebagai anggota cluster, dimana untuk Kota Jayapura sendiri adalah
SMA Negeri 4 sebagai koordinator cluster dengan anggota cluster terdiri atas SMA Negeri 3, SMA Negeri 2 dan SMA Mandala Trikora. Sekolah model terdiri atas sekolahsekolah yang melaksanakan Kurikulum 2013.

Berdasarkan sumber tersebut bahwa pelaksanaan Kurikulum 2013 telah dilaksanakan di empat sekolah yang ada di kota Jayapura yaitu SMA Negeri 2, SMA Negeri 3, SMA Negeri 4 dan SMA Mandala Trikora. Dari ke empat sekolah tersebut diharapkan telah mengimplementasikan Kurikulum 2013 ke dalam pembelajaran dan berjalan dengan baik serta lancar, sehingga dapat dijadikan sebagai bahan pertimbangan yang bermanfaat dalam memperbaiki pelaksanaan tersebut selanjutnya. Karena pada implementasi Kurikulum 2013 guru juga dituntut untuk dapat menjadi lebih baik dalam menciptakan suasana belajar peserta didik yang lebih aktif, sehingga untuk itu guru perlu memiliki empat kompetensi yang sesuai dengan Permendikbud Nomor 16 Tahun 2007 yaitu kompetensi pedagogis, profesional, kepribadian, dan sosial.

Struktur Kurikulum 2013 berdasarkan Permendikbud Nomor 59 Tahun 2014 dalam Pasal 3 ayat (1) merupakan pengorganisasian kompetensi inti, kompetensi dasar, muatan pembelajaran, mata pelajaran, dan beban 
belajar. Dalam pasal 5 mata pelajaran Sekolah Menengah Atas/Madrasah Aliyah sebagaimana dimaksud dalam Pasal 3 ayat (1) dikelompokkan atas: a) mata pelajaran umum Kelompok A; b) mata pelajaran umum Kelompok B; dan c) mata pelajaran peminatan akademik Kelompok C. Kelompok mata pelajaran $\mathrm{C}$ yaitu pilihan kelompok peminatan berdasarkan Permendikbud Nomor 64 Tahun 2014 terdiri atas peminatan Matematika dan Ilmu Pengetahuan Alam, peminatan Ilmu Pengetahuan Sosial, peminatan Bahasa dan Budaya serta peminatan Keagamaan (Anonimus 2014, Permendikbud Nomor 59 Tahun 2014. Jakarta). Mata pelajaran Kimia merupakan salah satu kelompok peminatan Matematika dan Ilmu Pengetahuan Alam.

Mata pelajaran Kimia di SMA/MA mempelajari segala sesuatu tentang zat yang meliputi komposisi, struktur dan sifat, perubahan, dinamika dan energetika zat yang melibatkan keterampilan dan penalaran. Untuk dalam mempelajari segala sesuatu tersebut harus melalui proses dan sikap ilmiah tertentu, dengan menggunakan proses dan sikap ilmiah itu kimiawan memperoleh penemuan-penemuan yang dapat berupa fakta, teori, hukum, dan prinsip. Oleh karena itu, pembelajaran kimia dan penilaian hasil belajar kimia harus memperhatikan karakteristik ilmu kimia sebagai sikap, proses dan produk. Selama ini ada kecenderungan sebagian guru kimia kurang memperhatikan karakteristik ilmu kimia dalam pembelajaran dan penilaian hasil belajar kimia.

\section{Berdasarkan karakteristik ilmu kimia} dalam pembelajaran dan penilaian hasil belajar kimia tentunya tidak terlepas dari standar kualifikasi akademik dan kompetensi guru di antaranya adalah kompetensi pedagogik dan kompetensi professional seperti menyelenggarakan pembelajaran yang mendidik dalam hal membuat perencanaan pembelajaran, melaksanakan pembelajaran, melakukan penilaian proses pembelajaran dan penilaan hasil pembelajaran. Keempat hal tersebut menjadi fokus penelitian tentang implementasi Kurikulum 2013 dalam pembelajaran kimia peserta didik kelas $\mathrm{X}$ sehingga dapat dikatakan bahwa kelemahan dari pengembangan profesi guru ini akan berakibat kurangnya kompetensi guru.

Dari beberapa hal yang ditelah dipaparkan di atas, dalam hal implementasi Kurikulum 2013 mata pelajaran kimia khususnya kelas $\mathrm{X}$ perlu dikaji lebih lanjut. Perlunya dilakukan identifikasi dan analisis terhadap faktor-faktor yang mempengaruhi pelaksanaan kurikulum 2013 secara objektif sehingga dapat memunculkan gambaran kekuatan dan kelemahan dari kinerja guru, peserta didik dan sekolah. Oleh karena itu penulis memusatkan kajian kepada "Implementasi Kurikulum 2013 Dalam 
Pembelajaran Kimia Kelas X SMA se-Kota Jayapura".

\section{METODOLOGI PENELITIAN}

Penelitian ini merupakan penelitian kualitatif. Tujuan dari penelitian ini adalah untuk mengevaluasi keterlaksanaan pembelajaran yang diterapkan guru mata pelajaran kimia kelas $\mathrm{X}$ terkait dengan implementasi Kurikulum 2013 yang ada di sekolah tersebut, hasil analisis implementasi tersebut akan dirujuk pada standarisasi yang telah ditetapkan oleh Mendikbud sebagai acuan pelaksanaan Kurikulum 2013. Sehingga jenis penelitian ini jika ditinjau dari cara penelitiannya termasuk penelitian deskriptif yang jenis kegiatannya merupakan penelitian evaluatif.

\section{Analisis Data}

Data yang diperoleh dari penelitian, selanjutnya dianalisis dengan menggunakan teknik analisa data deskripsif kualitatif. Deskripsi dilakukan dengan membandingkan data yang ada dengan standar yang ditentukan.

Dari data yang berasal dari instrumen-instrumen tersebut misalnya ada kaitannya atau perbedaan, kemudian peneliti mencari penyebab mengapa terjadi demikian, maka pemikiran peneliti tersebut disebut pembahasan. Membahas hasil analisis data adalah berpikir tentang kaitan antara data dan mungkin dengan latar belakang yang menyebabkan adanya persamaan atau perbedaan tersebut sehingga mendekatkan data yang diperoleh dengan kesimpulan peneliti. Sebagai standar digunakan adalah Permendikbud Nomor 59 Tahun 2014, Permendikbud Nomor 103 Tahun 2014 dan Permendikbud Nomor 104 Tahun 2014.

\section{HASIL PENELITIAN DAN PEMBAHASAN}

\section{Perencanaan Pembelajaran Kurikulum} 2013 Mata Pelajaran Kimia Kelas X SMA Se-Kota Jayapura

Perencanaan pembelajaran dengan menyusunan rencana pelaksanaan pembelajaran di SMA se-Kota Jayapura dilakukan dalam kegiatan Cluster dan dikembangkan oleh guru bidang studi masing-masing dengan tetap berpedoman pada prinsip pembelajaran kurikulum 2013 serta dengan mengkaji silabus yang meliputi: (1) KI dan KD; (2) materi pembelajaran; (3) proses pembelajaran; (4) penilaian pembelajaran; (5) alokasi waktu; dan (6) sumber belajar.

Hasil uraian dan kuisioner guru dalam implementasi kurikulum 2013 dalam perencanaan pembelajaran dapat terlaksana sesuai dengan Permendikbud Nomor 59 
tahun 2014 dan Permendikbud Nomor 103 Tahun 2014 sebesar 86\%, hal tersebut dimulai dari penyusunan RPP yang mengacu pada silabus dan prinsip-prinsip penyusunan RPP. Selain itu juga sekolah berperan aktif dalam menyiapkan berbagai sarana prasarana penunjang seperti perangkat penunjang pembelajaran, jaringan internet, LCD dan contoh-contoh RPP kurikulum 2013 serta kegiatan IHT yang diselenggarakan oleh Cluster sekolah pelaksana kurikulum 2013. Namun pada kenyataannya ada juga beberapa sekolah pelaksana Kurikulum 2013 yang antara lain belum mempergunakan laboratorium kimia sesuai dengan fungsinya, buku pedoman pembelajaran yang belum merata dimiliki peserta didik dan buku pedomana guru yang masih menggunakan kurikulum sebelumnya, sehingga tentunya akan mempengaruhi guru dalam merencanakan pelaksanaan pembelajaran. Menurut Interstate New Teacher Assessment and support Consortium (INTASC) dikutip dari Imas $\mathrm{K}$ dan Berlin 2014;23 standar bagi seorang guru yaitu harus memiliki pemahaman tentang: bidang ilmu, pengembangan potensi anak, berbagai strategi pembelajaran, pengelolaan kelas, kemampuan berkomunikasi, perencanaan pembelajaran, penilaian hasil belajar, komitmen dan menjalin hubungan dengan berbagai pihak maka salah satu cara yang bisa dilakukan adalah dengan ditingkatkannya kompetensi guru dengan kegiatan Musyawarah Guru Mata Pelajaran (MGMP) khususnya kimia.

Selain itu, kontrol untuk guru juga dilakukan dengan pelaksanaan supervisi oleh kepala sekolah karena menurut Darmuji (2014) dalam kesimpulannya Implementasi Kurikulum 2013 mata pelajaran pendidikan Agama Islam di SMPN 1 Pancangaan telah berjalan baik, namun masih ada beberapa penghambat yang solusinya adalah peningkatan supervisi dan motivasi semua pihak. Oleh karena itu, supervisi dan motivasi dari sekolah kepada guru menjadi salah satu faktor pendukung keberhasilan dalam mengimplementasikan kurikulum 2013.

\section{Hasil Belajar Pelaksanaan Pembelajaran Kurikulum 2013 Mata Pelajaran Kimia Kelas X SMA Se-Kota Jayapura.}

Peraturan Menteri Pendidikan dan Kebudayaan Nomor 81A Tahun 2013 tentang Implementasi Kurikulum pada lampiran IV: Pedoman Umum Pembelajaran, menjelaskan bahwa strategi pembelajaran sangat diperlukan dalam menunjang terwujudnya seluruh kompetensi yang dimuat dalam Kurikulum 2013. Dalam kegiatan pembelajaran kimia yang dilakukan berdasarkan data yang diperoleh tahapan pelaksanaan pembelajaran meliputi kegiatan pendahuluan, inti dan penutup. 
Kegiatan pendahuluan yang berpartisipasi aktif dalam proses dilakukan berupa apersepsi dan motivasi yang meliputi mengkondisikan suasana pembelajaran yang menyenangkan dapat terlaksana dengan keaktifan dari peserta didik, yang meliputi : (1) kegiatan absensi, (2) tanya jawab guru terhadap materi sebelumnya, (3) pembahasan kembali terhadap materi yang belum dikuasai peserta didik serta (4) mengadakan post-test oleh guru kimia sudah tampak diawal-awal kegiatan pembelajaran tetapi dalam penyampaian kompetensi, rencana kegiatan dan penilaian yang akan dilakukan belum berjalan semuanya secara optimal.

Kegiatan inti merupakan kegiatan pelaksanaan pembelajaran terpadu yang menekankan pada proses pembentukan pengalaman belajar peserta didik dengan tujuan guna mencapai kompetensi, yang dilakukan secara interaktif, inspiratif, menyenangkan, menantang, memotivasi peserta didik untuk berpartisipasi aktif, serta memberikan ruang yang cukup bagi prakarsa, kreativitas, dan kemandirian sesuai dengan bakat, minat dan perkembangan fisik serta psikologis peserta didik.

Pada proses pembelajaran kimia yang dilakukan secara keseluruhan telah berbasis aktifitas dengan karakteristik interaktif dan inspiratif dari peserta didik serta menyenangkan sekaligus menantang dan memotivasi peserta didik untuk pembelajaran di kelas. Proses pembelajaran dengan menggunakan pendekatan saintifik tidak terlepas dari penggunaan metodemetode lainnya seperti ceramah, diskusi, dan tanya jawab dimana metode pembelajaran tersebut merupakan cara atau teknik yang digunakan oleh guru untuk menangani suatu kegiatan pembelajaran yang telah direncanakan oleh guru yang menghendaki peserta didiknya lebih aktif dalam kelas.

Berdasarkan data yang diperoleh
dapat diketahui bahwa metode
pembelajaran kimia yang dipilih oleh guru
pembelajaran kimia yang dipilih oleh guru telah menggunakan pendekatan saintifik dalam proses pembelajarannya, dimana sebagian besar mengacu pada pembelajaran yang berbasis aktivitas dengan berpusat pada peserta didik sebagai subjek belajar dengan karakteristik kontekstual dan kolaboratif. Dari pendekatan pembelajaran yang telah ditetapkan, selanjutnya diturunkan kedalam strategi pembelajaran.

Kegiatan penutup merupakan kegiatan untuk menutup pelajaran, dalam kegiatan akhir pembelajaran guru (a) membuat rangkuman atau simpulan pelajaran yang dilakukan peserta didik dengan dibantu guru untuk penekanan pada substansi tujuan pembelajaran; melakukan refleksi terhadap kegiatan yang sudah dilaksanakan baik itu, kegiatan yang 
baru terjadi dengan penekanan terhadap halhal yang boleh dan tidak boleh dilakukan dalam proses pembelajaran disertai dengan nasehat yang membentuk sikap dan kepribadian peserta didiknya.; dan (c) memberikan umpan balik terhadap proses dan hasil pembelajaran seperti melaksanakan tes akhir yang berpatokan terhadap indikator pembelajaran; tetapi perlu diperhatikan adalah ketersediaan waktu untuk kegiatan penutup yang relatif singkat. Oleh karena itu guru perlu mengatur dan memanfaatkan waktu seefisien mungkin.

\section{Penilaian Proses Pembelajaran}

Kurikulum 2013 Mata Pelajaran Kimia

Kelas X SMA Se-Kota Jayapura.

Penilaian nyata (authentic assessment) adalah proses yang dilakukan guru untuk mengumpulkan informasi tentang perkembangan belajar yang dilakukan peserta didik. Penilaian ini diperlukan untuk mengetahui apakah peserta didik benar-benar belajar atau tidak, apakah pengalaman belajar peserta didik memiliki pengaruh yang posistif terhadap perkembangan, baik intelektual ataupun mental peserta didik. Penilaian yang dilakukan mencangkup terhadap aspek sikap (afektif), pengetahuan (kognitif) dan ketrampilan (psikomotor).

Aspek sikap yang bisa diperhatikan dalam proses pembelajaran khususnya di kelas dan hasil pengamatan adalah peserta didik menjadi lebih antusias, lebih termotivasi, suasana pembelajaran yang menyenangkan sehingga menumbuhkan minat belajar kimia dan memudahkan dalam menyerap materi serta adanya sikap patuh dan menghormati guru dalam membimbing proses pembelajaran. Namun pada kenyataan dilapangan para guru kimia pelaksana kurikulum 2013 sempat mengeluhkan sulitnya melaksanakan keseluruhan penilaian yang mencangkup aspek sikap, pengetahuan dan ketrampilan apabila dilakukan sekaligus dalam satu kali pertemuan.

Penilaian aspek pengetahuan dilakukan guru setelah mempelajari suatu kompetensi dasar yang harus dicapai, akhir dari semester dan jenjang satuan pendidikan. Kompetensi dasar yang hendak dicapai berupa pemahaman konsep, prinsip dan hukum. Pelaksanaan penilaian dalam proses pembelajaran di awali dengan penelusuran dan di akhiri dengan tes dan/atau nontes. Penelusuran dilakukan guru dengan menggunakan teknik bertanya untuk mengeksplorasi pengalaman belajar sesuai dengan kondisi dan tingkat kemampuan peserta didik. Proses penilaian yang dilakukan guru diawali dengan mengkaji silabus sebagai acuan dalam membuat rancangan dan kriteria penilaian pada awal semester kemudian memilih teknik penilaian sesuai dengan indikator 
dan mengembangkan instrumen serta pedoman penyekoran sesuai dengan teknik penilaian yang dipilih.

Pada penilaian ketrampilan yang dapat dikembangkan sesuai dengan kompetensi yang diharapkan adalah ranah abstrak dan ranah konkret. Pada ranah abstrak cenderung pada ketrampilan seperti menyajikan, mengolah, menalar, dan mencipta dengan domain pada kemampuan berpikir tanpa bantuan alat. Sedangkan untuk ranah konkret cenderung pada kemampuan fisik seperti menggunakan alat, mencoba, membuat, memodifikasi dan menciptakan dengan bantuan alat. Sehingga dalam melakukan penilaian aspek ketrampilan guru kimia melakukan melalui tes praktik, proyek dan portofolio dalam pembelajaran kimia adalah melakukan praktikum di laboratorium dengan segala keterbatasan sarana prasarananya. Alasan sama yang dikemukakan adalah dalam pembelajaran kimia materi untuk kelas $X$ di dominasi oleh pembelajaran yang sifatnya teori dan hitungan sehingga pada penilaian praktik hanya dilaksanakan satu kali dalam semester ganjil ini yaitu pada waktu awal semester.

Pada penilaian projek dalam pelaksanaannya di kelas guru kimia belum menerapkannya karena dalam kegiatan penilaiannya dilakukan dalam periode atau waktu tertentu dimana membutuhkan suatu investigasi mulai dari perencanaan, pengumpulan data, pengorganisasian, pengolahan dan penyajian data. Sedangkan penilaian portofolio yang dilakukan oleh guru kimia dalam bentuk membuat laporan praktikum kimia yang terkendala kepada pengelolaan pemanfaatan fasilitas laboratorium kimia. Namun dalam kompetensi guru dituntut harus mempunyai kepribadian yang matang dan berkembang; menguasai ilmu pengetahuan dan teknologi kuat; ketrampilan untuk membangkitkan minat peserta didik; dan mengembangkan profesinya secara berkesinambungan.

\section{Penilaian Hasil Pembelajaran Kurikulum 2013 Mata Pelajaran Kimia Kelas X SMA Se-Kota Jayapura.}

Hasil belajar yang dicantumkan dalam bentuk rapor berupa ranah sikap menggunakan skor modus $1,00-4,00$ dengan predikat kurang baik $(\mathrm{K})$, cukup (C), baik (B) dan sangat baik (SB); untuk ranah pengetahuan menggunakan skor rerata $1,00-4,00$ dengan predikat $\mathrm{D}-\mathrm{A}$; dan untuk ranah ketrampilan menggunakan skor optimum 1,00 - 4,00 dengan predikat D - A. Hasil belajar ranah sikap, pengetahuan dan ketrampilan tidak dijumlahkan karena dimensinya yang diukur berbeda dimana masing-masing dilaporkan sendiri-sendiri dan memiliki makna yang sama penting, hal ini dikarenakan ada peserta didik yang memiliki kemampuan pengetahuan yang 
tinggi dan kemampuan ketrampilan cukup. Sebaliknya ada juga peserta didik yang memiliki kemampuan pengetahuan yang cukup tetapi kemampuan ketrampilan yang tinggi. Bila skor kedua kemampuan peserta didik tersebut dijumlahkan maka bisa terjadi skor yang sama sehingga tampak sama kemampuan kedua peserta didik tersebut walaupun sebenarnya karakteristik kemampuan mereka berbeda.

Untuk penilaian tes awal, tes akhir dan tugas-tugas guru kimia masih menggunakan penilaian skala $0-100$ dengan maksud memudahkan penilaian yang biasa dilakukan, kemudian mengkonversinya ke skala 1,00 - 4,00 yang sesuai dengan kurikulum 2013. Hal ini sebenarnya mengindikasikan bahwa guruguru pelaksana kurikulum 2013 belum terbiasa/familier terhadap skala penilaian pada kurikulum 2013 untuk itu perlunya pembiasaan terhadap penggunaannya agar nantinya menyebabkan guru tidak harus bekerja dua kali dalam mengolah nilai dengan cara mengkonversikannya lagi.

Pemanfaatan hasil sebagai laporan kemajuan belajar peserta didik merupakan sarana komunikasi dan hubungan kerjasama antara sekolah, peserta didik dan orang tua. dimana proses pelaporan hasil belajar peserta didik merupakan tahapan dari serangkaian suatu proses pendidikan di sekolah yang harus dilewati sehingga pemanfaatnya dapat berdampak untuk (1) peserta didik untuk mengetahui kemajuan hasil belajar diri. (2) orang tua guna membantu anaknya belajar, memotivasi anaknya belajar, membantu sekolah meningkatkan hasil belajar peserta didik dan membantu sekolah melengkapi fasilitas belajar. (3) guru dan kepala sekolah untuk mengetahui kekuatan dan kelemahan peserta didik dalam satu kelas dan sekolah dalam semua mata pelajaran yang nantinya mendorong guru untuk mengajar lebih baik, menentukan strategi mengajar yang lebih tepat dan mendorong sekolah memberikan fasilitas belajar lebih baik (M.Hosnan, 2014;430).

\section{SIMPULAN DAN SARAN}

\section{Simpulan}

1. Perencanaan pembelajaran Kurikulum 2013 mata pelajaran kimia kelas $\mathrm{X}$ di SMA Se-Kota Jayapura dapat terlaksana sesuai dengan Permendikbud Nomor 59 Tahun 2014 dan Nomor 103 Tahun 2014 serta didukung hasil kuisioner guru yang mencapai $86 \%$.

2. Pelaksanaan pembelajaran Kurikulum 2013 mata pelajaran kimia kelas X di SMA Se-Kota Jayapura dapat terlaksana sesuai dengan Permendikbud Nomor 103 Tahun 2014 dan didukung hasil kuisioner guru yang mencapai $86 \%$.

3. Penilaian proses pembelajaran Kurikulum 2013 mata pelajaran kimia kelas X di SMA Se-Kota Jayapura dapat 
terlaksana sesuai dengan Permendikbud Nomor 103 Tahun 2014 dan Nomor 104 Tahun 2014 serta didukung hasil kuisioner guru yang mencapai $81 \%$.

4. Penilaian hasil pembelajaran Kurikulum 2013 mata pelajaran kimia kelas X di SMA Se-Kota Jayapura dapat terlaksana sesuai dengan Permendikbud Nomor 104 Tahun 2014 dan didukung hasil kuisioner guru yang mencapai $87 \%$.

\section{Saran}

1. Penerapan pembelajaran inkuiri terbimbing yang dipadu dengan diagram alir perlu dilanjutkan pada konsep-konsep kimia yang lain yang melibatkan kegiatan laboratorium, karena pembelajaran ini sangat membantu siswa dalam menganalisis langkah-langkah yang harus dilakukan sebelum kegiatan eksperimen.

2. Pembelajaran inkuiri terbimbing yang dipadu diagram alir dapat dilaksanakan pada semua jenjang pendidikan, karena pembelajaran ini mengajak siswa untuk berpikir secara maksimal sehingga tingkat pemahaman siswa terhadap konsep yang dipelajari meningkat.

3. Perlu dilakukan Penelitian lebih lanjut tentang pengaruh diagram alir dalam pembelajaran inkuiri terbimbing pada materi yang sama maupun berbeda dengan melibatkan subjek Penelitian yang lebih luas, karena adanya fase-fase dalam pembelajaran inkuiri terbimbing dan langkah-langkah yang ada pada diagram alir dapat meningkatkan kualitas proses dan hasil belajar siswa.

\section{DAFTAR PUSTAKA}

Arifin, Daeng dan Pipin Arifin. 2011. Keprofesionalan Seorang Guru. Bandung : Pustaka Al Kasyaf.

Arikunto, Suharsimi. 2010. Prosedur Penelitian : Suatu Pendekatan Praktik. Jakarta : Rineka Cipta.

Creswell, John W. 2012. Research Design : Pendekatan Kualitatif, Kuantitatif, dan Mixed. Penerjemah Ahmad Fawaid. Yogyakarta : Pustaka Pelajar.

Darmuji. 2014. Implementasi Kurikulum 2013 Mata Pelajaran Pendidikan Agama Islam Di SMPN 1 Pencangaan Jepara Tahun Pelajaran 2013/2014..

Direktorat Pembinaan SMA, Ditjen Pendidikan Menengah, 2014. Pembelajaran Kimia dengan Pendekatan Saintifik.

Imas Kurniasih dan Berlin Sani. Cetakan Kedua, 2014. Sukses Mengimplementasikan Kurikulum 2013 : Memahami Berbagai Aspek Dalam Kurikulum 2013. Surabaya : Kata Pena.

Joko Saryono. 2009. Implementasi Kurikulum Tingkat Satuan Pendidikan Di Sekolah Menengah 
Pertama Sultan Agung Salaman

Kabupaten Magelang. Tesis;

Universitas Sebelas Maret. Surakarta.

M. Hosnan. 2014. Pendekatan Saintifik Dan

Kontekstual Dalam Pembelajaran

Abad 21. Jakarta : Ghalia Indonesia.

Mulyasa, E. 2013. Menjadi Guru

Profesional: Menciptakan

Pembelajaran Kreatif dan

Menyenangkan. Bandung :

Rosdakarya.

Nabire Net. 2014. Penerapan Kurikulum

2013 di Papua. Info Рapua, 10 (1),

(online), (http://www.nabire.net/),

diunduh tanggal 25 Agustus 2014

Peraturan Menteri Pendidikan dan

Kebudayaan Republik Indonesia

Nomor 59 Tahun 2014 tentang

Kurikulum 2013 Sekolah Menengah

Atas/Madrasah Aliyah. 